\title{
Seismic Analysis of Building with and Without Shear Wall for Building with RCC and Composite Column
}

\author{
${ }^{1}$ Akansha Dwivedi \\ ${ }^{1}$ Post Graduate Student in Structural Engineering, \\ Department of Civil Engineering, \\ Radha Govind Engineering College, \\ Meerut, UP ,India
}

\begin{abstract}
Shear wall is a structural element which is provided for resisting horizontal forces (like wind force, earthquake force, etc) parallel to the plane of the wall and for supporting gravity loads simultaneously. These are basically flexural members which are generally provided in high rise buildings to avoid the total collapse of the building exposed to seismic forces. For seismic design of buildings, RC structural walls or shear walls are major earthquake resisting members which offer lateral load resistance by providing an efficient bracing system.

The response of the buildings is dominated by the properties of seismic shear walls and so it becomes important to evaluate the seismic response of the shear walls appropriately. In this study, the effect of presence of shear walls in RCC and composite structures in being analysed on basis of storey displacement, storey drift, stiffness, lateral force and base shear for $\mathbf{G + 1 9}$ buildings. Effectiveness of shear wall is being studied with the help of four different models. Model 1 is RCC building without shear wall, Model 2 is RCC building with shear wall, Model 3 is building with composite columns having no shear wall and Model $\mathbf{4}$ is building with composite columns in presence of shear wall. The earthquake load is applied to a building in zone IV and the analysis is done using both static analysis method and response spectrum analysis method.
\end{abstract}

Keywords: ETAB 2017, RCC buildings, Building with steelconcrete composite columns, Seismic analysis, Shear wall.

\section{INTRODUCTION}

In recent time, a lot of effort is given to develop the structural control devices so that seismic impact in buildings can be reduced. One such practice is introduction of shear wall in the buildings. Shear walls are one of the best means to provide earthquake resistance in multistoried building. Behaviour of building under earthquake load depends on how the weight, stiffness and strength are distributed in the horizontal and lateral direction. Shear walls are used in the building to reduce the effect of earthquake by improving the seismic response of buildings. It becomes important to ensure adequate lateral stiffness to resist lateral load. For high- rise buildings, beam and column sizes are very heavy and requirement of steel is large because of which there is a lot of congestion at the joints and making it difficult to vibrate concrete at the joints and also the displacement is quite heavy.

In India most of the buildings are low rise. So, RCC members are used widely as it is easy to construct and

\author{
${ }^{2}$ B.S Tyagi \\ ${ }^{2}$ Professor, \\ Department of Civil Engineering, \\ Radha Govind Engineering College, \\ Meerut, UP, India
}

is economical. However with the growth of population there is increasing growth in high-rise buildings in metropolis. It is observed that the use of composite members over RCC members is much more effective and economical in high rise buildings. When a steel component like I-beam is attached to a concrete component like floor slab or bridge deck, a composite member is formed. In composite structures the high strength of the concrete in compression and high strength of the steel in tension are utilized in combination. Thus steel- concrete composite construction makes use of compressive strength of concrete and tensile strength of steel together to give more economical and effective structure. Such an advanced system is gaining recognition in high rise buildings.

In this paper effectiveness of shear wall in RCC building and building with composite columns have been studied with the help of four different models using Etabs in zone IV. The analysis is done by response spectrum analysis method and static analysis method. The models considered for the analysis are as follows:

Model 1 is RCC building without shear wall,

Model 2 is RCC building with shear wall,

Model 3 is building with composite columns having no shear wall and

Model 4 is building with composite columns in presence of shear wall.

\section{BUILDING MODELING}

For the analysis 20 storey building has been considered having a height of $3 \mathrm{~m}$ for each story including the ground storey. The structure modelled in symmetrical about both the axis. The modelling has been done in accordance to IS 456 and IS 1893 .The buildings has the fixed support at the base. The buildings are modelled using software ETAB for zone IV. Centre to centre distance between the two consecutive columns are $4 \mathrm{~m}$, the columns provided is square as they resist earthquake loading better. The study is carried out for the same building plan with and without shear wall for both RCC columns and composite columns by making four different models. Equivalent static method and response spectrum method have been used for the analysis and analysis has been done considering the parameters like storey displacement, storey drift, stiffness , lateral force and base shear . 
Table 1: Building description

\begin{tabular}{|l|l|}
\hline Building storey & G+19 \\
\hline Total height of building & $60 \mathrm{~m}$ \\
\hline Height of each storey & $3.0 \mathrm{~m}$ \\
\hline Beam size & $350 \mathrm{~mm} \times 700 \mathrm{~mm}$ \\
\hline Column size & $600 \mathrm{~mm}$ X $600 \mathrm{~mm}$ \\
\hline Shear wall thickness & $250 \mathrm{~mm}$ \\
\hline Slab thickness & $225 \mathrm{~mm}$ \\
\hline Thickness of external walls & $230 \mathrm{~m}$ \\
\hline Thickness of internal walls & 115 \\
\hline Live load & $3 \mathrm{KN} / \mathrm{m}^{2}$ \\
\hline Floor finish & $2 \mathrm{KN} / \mathrm{m}^{2}$ \\
\hline Grade of Concrete & $\mathrm{M} 30$ \\
\hline Grade of reinforcing Steel & $\mathrm{HYSD} 415$ \\
\hline Grade of Steel & $\mathrm{Fe} 250$ \\
\hline Density of Concrete & $25 \mathrm{KN} / \mathrm{m} 3$ \\
\hline Zone & $\mathrm{IV}$ \\
\hline Importance factor & 1.2 \\
\hline Soil condition & Medium soil \\
\hline Response reduction factor & 5.0 \\
\hline Damping ratio & $5 \%$ \\
& \\
\hline & \\
\hline
\end{tabular}

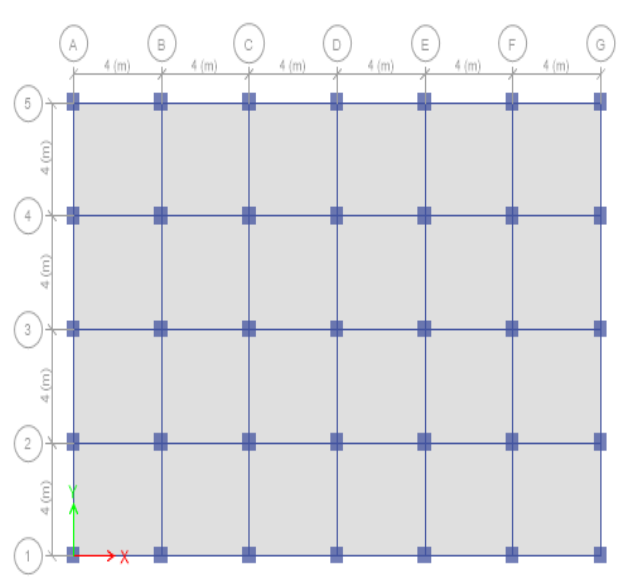

Fig 1: Plan view of building without shear wall

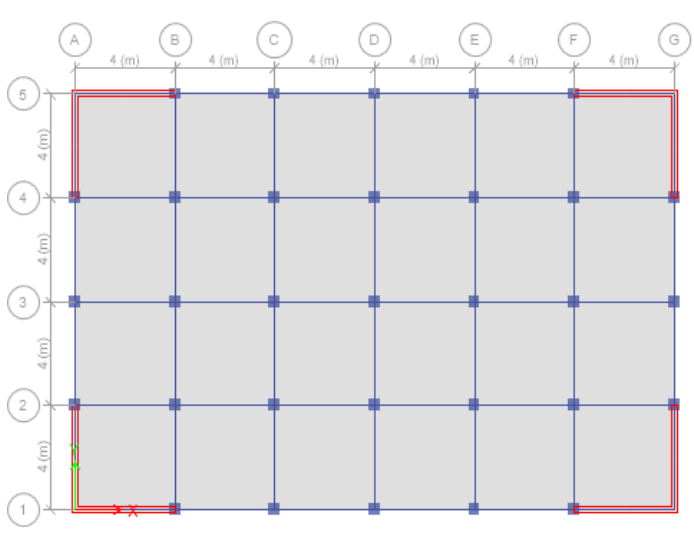

Fig 3: Plan view of building with shear

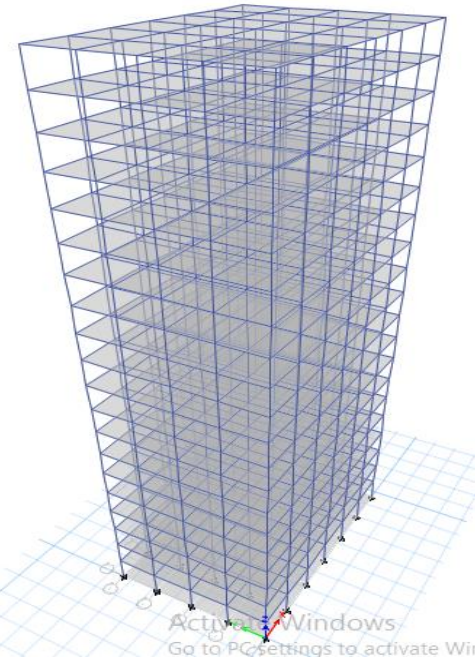

Fig 2: Elevation view of building without shear wall

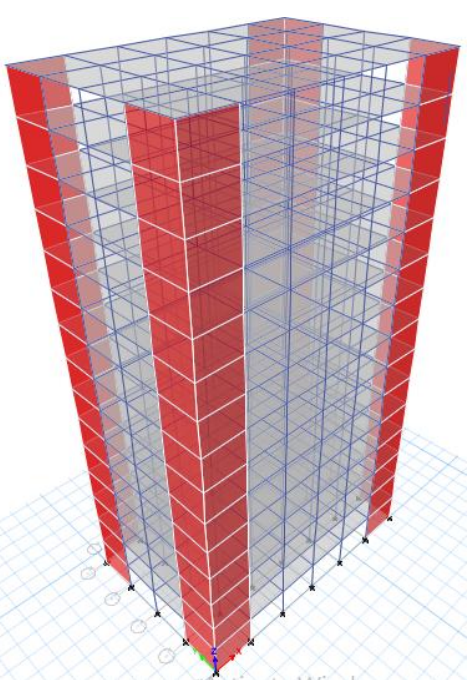

Fig 4: Elevation view of building with shear wall 


\section{RESULTS AND DISCUSSIONS}

Equivalent static method and response spectrum method is used to analyse the results of all four models. Loads are calculated and distributed as per IS 1893:2016 and results obtained is compared as per following parameters.

\subsection{STATIC ANALYSIS OF G+19 BUILDINGS}

1. Lateral Displacement- From the observed results it was found that building with composite column in presence of shear wall showed minimum displacement. Also it is observed that the building on introduction of shear wall reduced displacement in the building substantially.

Table 2: Storey displacement

\begin{tabular}{|r|r|r|r|r|}
\hline \multicolumn{1}{|c|}{ STOREY } & $\begin{array}{c}\text { RCC } \\
(\mathbf{m m})\end{array}$ & $\begin{array}{c}\text { RCC WITH SHEAR WALL } \\
(\mathbf{m m})\end{array}$ & $\begin{array}{c}\text { COMPOSITE } \\
(\mathbf{m m})\end{array}$ & $\begin{array}{c}\text { COMPOSITE WITH SHEAR WALL } \\
(\mathbf{m m})\end{array}$ \\
\hline 1 & 6.562 & 1.427 & 4.123 & 1.154 \\
\hline 2 & 17.534 & 4.305 & 12.168 & 3.458 \\
\hline 3 & 29.419 & 8.29 & 21.505 & 6.599 \\
\hline 4 & 41.539 & 13.165 & 31.266 & 10.43 \\
\hline 5 & 53.728 & 18.744 & 41.146 & 14.814 \\
\hline 6 & 65.909 & 24.868 & 51.019 & 19.637 \\
\hline 7 & 78.016 & 31.398 & 60.809 & 24.794 \\
\hline 8 & 89.979 & 38.211 & 70.457 & 30.192 \\
\hline 9 & 101.723 & 45.199 & 79.902 & 35.748 \\
\hline 10 & 113.168 & 52.261 & 89.078 & 41.386 \\
\hline 11 & 124.227 & 59.311 & 97.917 & \\
\hline 12 & 134.808 & 66.271 & 106.344 & 47.037 \\
\hline 13 & 144.813 & 73.071 & 114.28 & \\
\hline 14 & 154.139 & 79.655 & 121.64 & 5.638 \\
\hline 15 & 162.678 & 85.977 & 128.336 & \\
\hline 16 & 170.318 & 92.002 & 134.274 & \\
\hline 17 & 176.943 & 97.714 & 139.363 & \\
\hline 18 & 182.435 & 103.115 & 143.517 & \\
\hline 19 & 186.693 & 108.234 & 146.69 & \\
\hline 20 & 189.744 & 113.06 & 148.965 & \\
\hline & & & & \\
\hline
\end{tabular}

\section{Displacement (mm)}

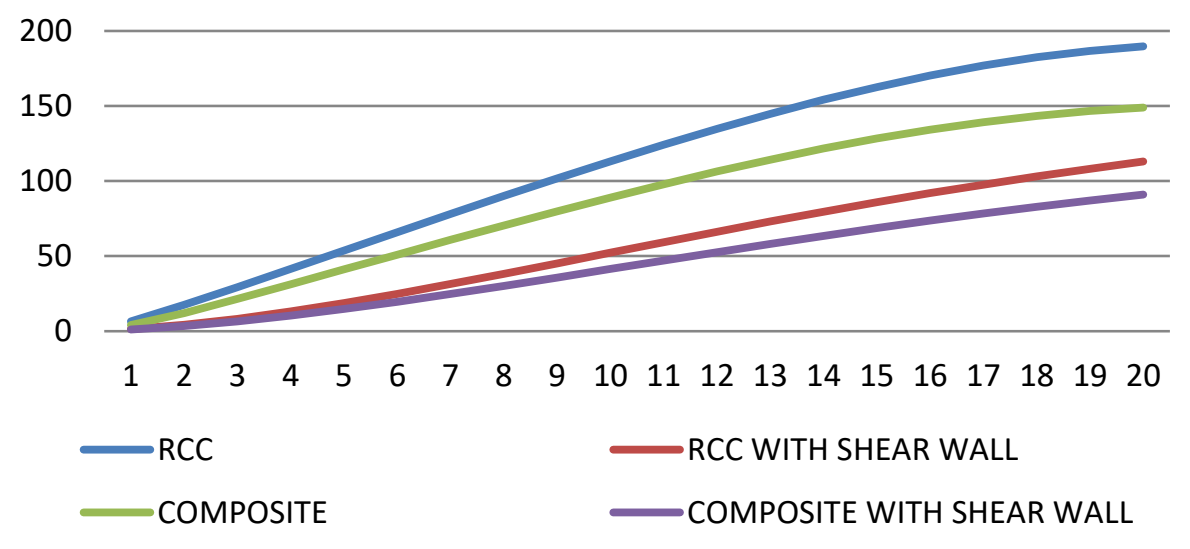

Fig 5: Comparison of storey displacement

2. Storey Drift-Decrease in storey drift was observed in presence of shear wall in both building with RCC column as well as building with Composite column. Maximum drift was observed in RCC building without shear wall.

Table 3: Storey drift

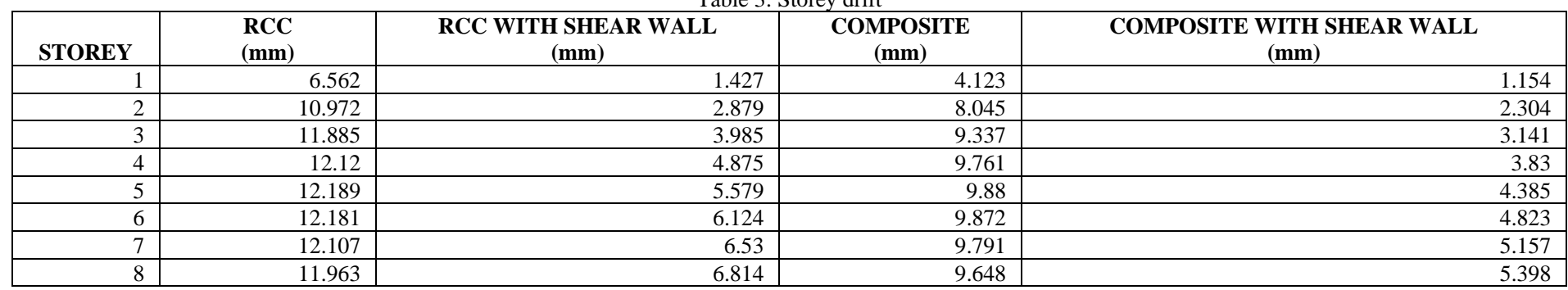




\begin{tabular}{|c|c|c|c|c|}
\hline 9 & 11.744 & 6.987 & 9.444 & 5.556 \\
\hline 10 & 11.445 & 7.063 & 9.176 & 5.638 \\
\hline 11 & 11.059 & 7.05 & 8.839 & 5.651 \\
\hline 12 & 10.581 & 6.959 & 8.427 & 5.602 \\
\hline 13 & 10.005 & 6.801 & 7.936 & 5.499 \\
\hline 14 & 9.326 & 6.584 & 7.36 & 5.349 \\
\hline 15 & 8.539 & 6.321 & 6.696 & 5.161 \\
\hline 16 & 7.64 & 6.025 & 5.939 & 4.944 \\
\hline 17 & 6.624 & 5.712 & 5.089 & 4.511 \\
\hline 18 & 5.492 & 4.702 & 4.154 & 3.673 \\
\hline 19 & 4.258 & 3.719 & 3.172 & 2.855 \\
\hline 20 & 3.051 & 2.64 & 2.276 & 1.984 \\
\hline
\end{tabular}

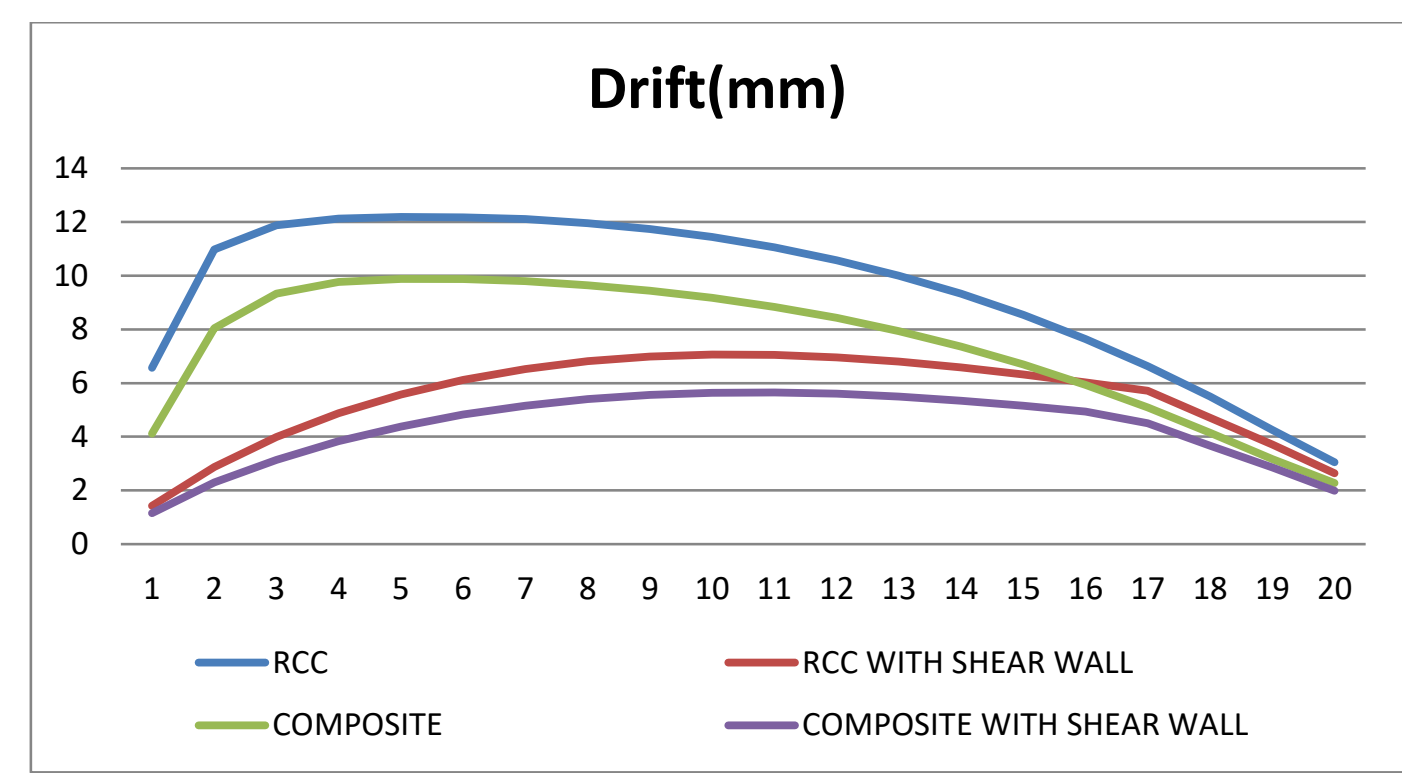

Fig 6: Storey drift

3. Stiffness- It is observed that building with composite column having shear wall has maximum stiffness and RCC building without shear wall shows minimum stiffness as evident from the graph below.

\begin{tabular}{|c|c|c|c|c|}
\hline Base & 0 & ( & (2) & 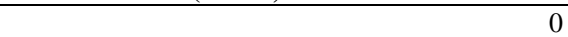 \\
\hline 1 & 1268830 & 6058615.79 & 2062814.746 & 7645668.716 \\
\hline 3 & 699311.8 & 2164984.441 & 909335.751 & 2803316.998 \\
\hline 4 & 683496.6 & 1764036.19 & 867034.373 & 2291679.015 \\
\hline 5 & 675719.4 & 1532494.518 & 851613.092 & 1990302.456 \\
\hline 6 & 670043.4 & 1383341.694 & 844533.12 & 1793098.3 \\
\hline 9 & 657014.2 & 1146030.216 & 834587.182 & 1471074.498 \\
\hline 10 & 653038.4 & 1098099.278 & 831982.827 & 1404090.936 \\
\hline 11 & 648797.8 & 1055899.696 & 829154.648 & 1344609.27 \\
\hline 12 & 643937.4 & 1015525.479 & 825782.217 & 1287617.095 \\
\hline 13 & 637982.4 & 973324.746 & 821441.032 & 1228487.908 \\
\hline 14 & 630252.7 & 925436.317 & 815506.837 & 1162426.33 \\
\hline 20 & 308690.8 & 197581.503 & 419907.19 & 242734.859 \\
\hline
\end{tabular}




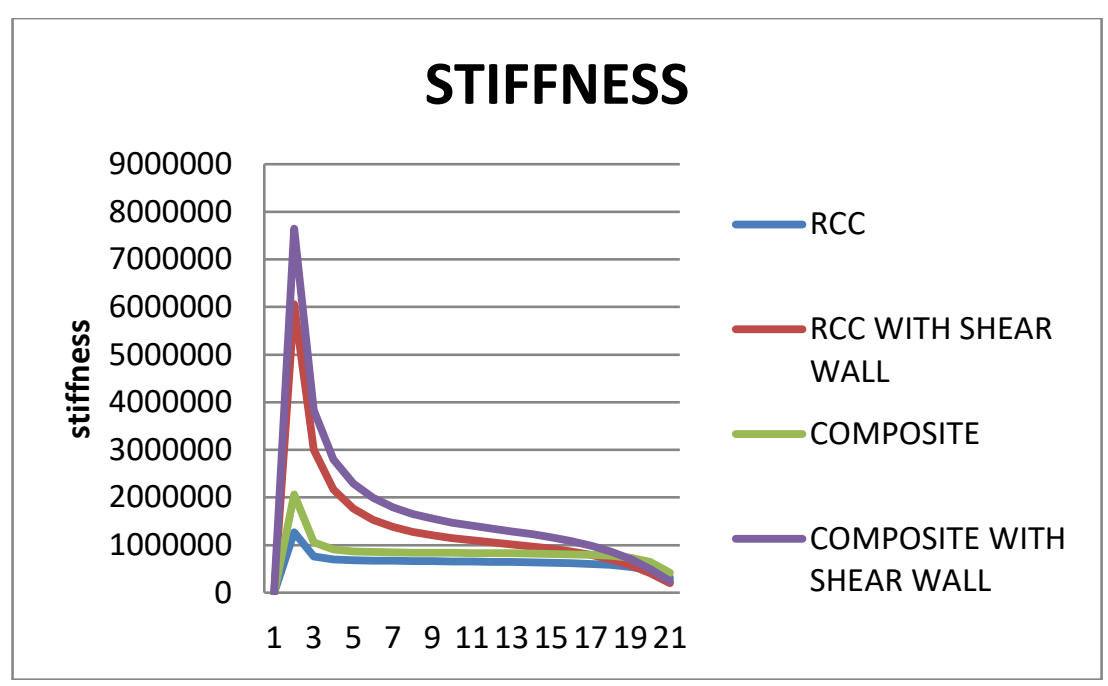

Fig 7: Comparison of stiffness

Fig 9: Representation of base shear for different models

\subsection{RESPONSE SPECTRUM ANALYSIS OF G+19 BUILDINGS}

1. Lateral displacement- It is observed that displacement is reduced substantially in presence of shear wall. Building with composite column in presence of shear wall showed minimum displacement while the RCC building without shear wall showed maximum displacement.

Table 6: Lateral displacement by response spectrum

\begin{tabular}{|c|c|c|c|c|}
\hline STOREY & $\begin{array}{l}\mathrm{RCC} \\
(\mathbf{m m})\end{array}$ & $\begin{array}{c}\text { RCC WITH SHEAR WALL } \\
(\mathbf{m m})\end{array}$ & $\begin{array}{l}\text { COMPOSITE } \\
(\mathbf{m m})\end{array}$ & $\begin{array}{l}\text { COMPOSITE WITH SHEAR WALL } \\
(\mathrm{mm})\end{array}$ \\
\hline 1 & 4.295 & 0.835 & 2.682 & 0.678 \\
\hline 2 & 11.3 & 2.413 & 7.815 & 1.947 \\
\hline 3 & 18.614 & 4.509 & 13.597 & 3.601 \\
\hline 4 & 25.759 & 6.984 & 19.422 & 5.546 \\
\hline 5 & 32.64 & 9.725 & 25.084 & 7.699 \\
\hline 6 & 39.241 & 12.64 & 30.519 & 9.993 \\
\hline 7 & 45.563 & 15.659 & 35.711 & 12.376 \\
\hline 8 & 51.605 & 18.726 & 40.653 & 14.805 \\
\hline 9 & 57.358 & 21.798 & 45.341 & 17.25 \\
\hline 10 & 62.811 & 24.844 & 49.767 & 19.686 \\
\hline 11 & 67.948 & 27.842 & 53.918 & 22.095 \\
\hline 12 & 72.752 & 30.774 & 57.781 & 24.464 \\
\hline 13 & 77.205 & 33.627 & 61.341 & 26.782 \\
\hline 14 & 81.289 & 36.393 & 64.584 & 29.042 \\
\hline 15 & 84.985 & 39.062 & 67.495 & 31.235 \\
\hline 16 & 88.27 & 41.63 & 70.056 & 33.356 \\
\hline 17 & 91.115 & 44.092 & 72.244 & 35.399 \\
\hline 18 & 93.486 & 46.45 & 74.034 & 37.362 \\
\hline 19 & 95.346 & 48.713 & 75.414 & 39.251 \\
\hline 20 & 96.714 & 50.871 & 76.423 & 41.038 \\
\hline
\end{tabular}




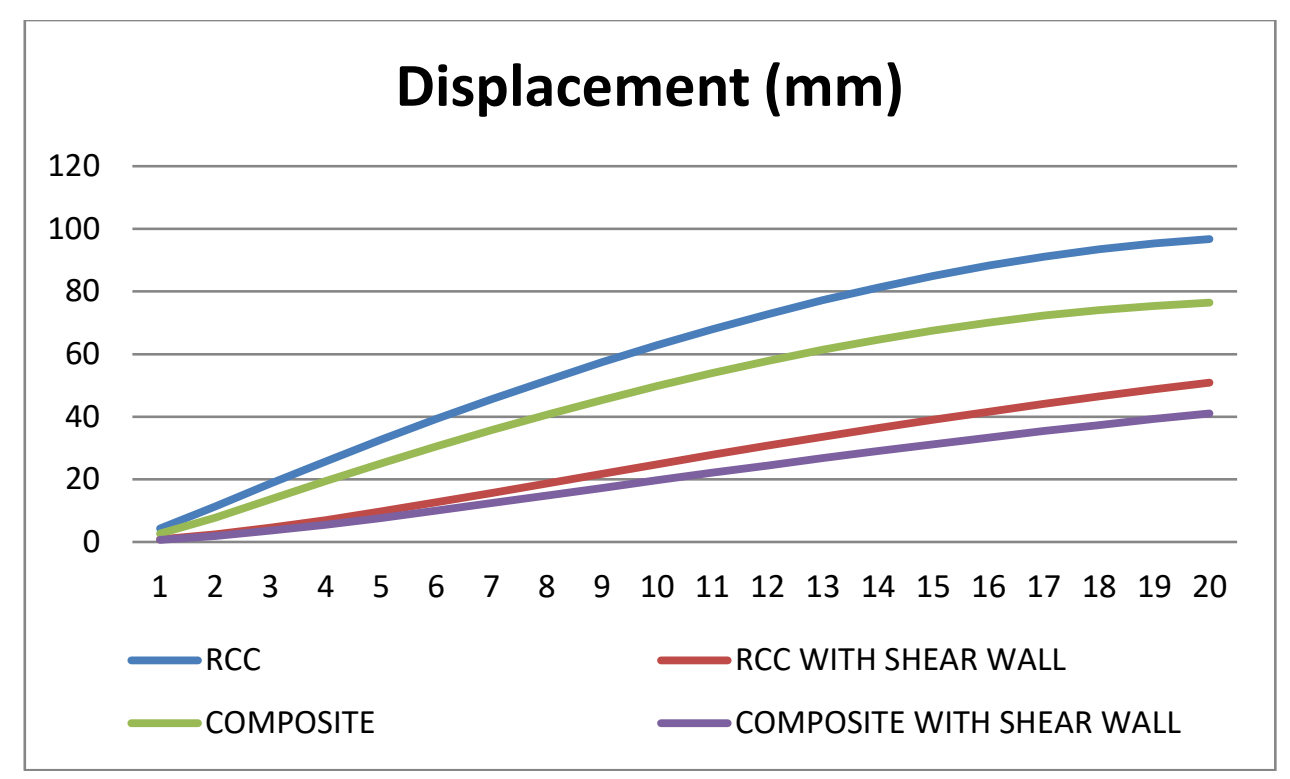

Fig 10: Comparison of displacement by response spectrum method

2. Lateral drift- There is decrease in drift in building with composite column than building with RCC column. Building with composite column in presence of shear wall showed minimum drift among all the four models

\begin{tabular}{|c|c|c|c|c|}
\hline STOREY & $\begin{array}{l}\mathbf{R C C} \\
(\mathbf{m m})\end{array}$ & $\begin{array}{l}\text { RCC WITH SHEAR WALL } \\
(\mathbf{m m})\end{array}$ & $\begin{array}{l}\text { COMPOSITE } \\
(\mathbf{m m})\end{array}$ & $\begin{array}{l}\text { COMPOSITE WITH SHEAR WALL } \\
(\mathbf{m m})\end{array}$ \\
\hline 1 & 4.295 & 0.835 & 2.682 & $\begin{array}{ll} & 0.678 \\
\end{array}$ \\
\hline 2 & 7.015 & 1.581 & 5.136 & 1.271 \\
\hline 3 & 7.355 & 2.103 & 5.801 & 1.66 \\
\hline 4 & 7.243 & 2.49 & 5.874 & 1.956 \\
\hline 5 & 7.059 & 2.766 & 5.764 & 2.173 \\
\hline 6 & 6.87 & 2.957 & 5.605 & 2.327 \\
\hline 7 & 6.683 & 3.082 & 5.435 & 2.433 \\
\hline 8 & 6.483 & 3.158 & 5.259 & 2.501 \\
\hline 9 & 6.269 & 3.197 & 5.07 & 2.543 \\
\hline 10 & 6.033 & 3.209 & 4.865 & 2.564 \\
\hline 11 & 5.777 & 3.202 & 4.641 & 2.569 \\
\hline 12 & 5.505 & 3.177 & 4.404 & 2.561 \\
\hline 13 & 5.214 & 3.137 & 4.155 & 2.539 \\
\hline 14 & 4.904 & 3.081 & 3.891 & 2.503 \\
\hline 15 & 4.567 & 3.007 & 3.606 & 2.452 \\
\hline 16 & 4.18 & 2.913 & 3.28 & 2.383 \\
\hline 17 & 3.717 & 2.801 & 2.891 & 2.297 \\
\hline 18 & 3.146 & 2.673 & 2.42 & 2.097 \\
\hline 19 & 2.436 & 2.141 & 1.865 & 1.592 \\
\hline 20 & 1.665 & 1.286 & 1.304 & 0.95 \\
\hline
\end{tabular}




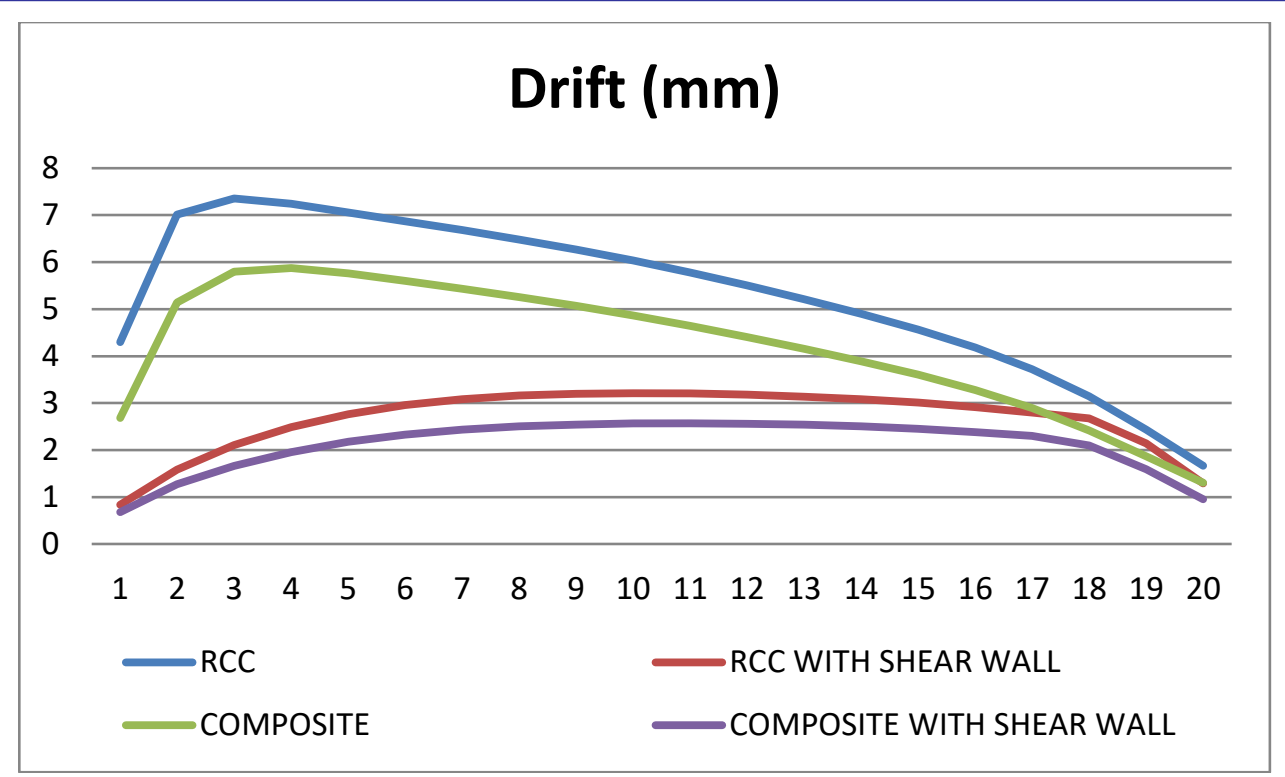

Fig 11: Comparison of drift by response spectrum method

4. Stiffness- It is observed that building with composite column having shear wall has maximum stiffness and RCC building without shear wall shows minimum stiffness as evident from the graph below.

Table 7: Lateral drift by response spectrum

\begin{tabular}{|c|c|c|c|c|}
\hline STOREY & $\begin{array}{c}\text { RCC } \\
(\mathrm{KN} / \mathrm{m})\end{array}$ & $\begin{array}{l}\text { RCC WITH SHEAR WALL } \\
(\mathrm{KN} / \mathrm{m})\end{array}$ & $\begin{array}{c}\text { COMPOSITE } \\
(\mathrm{KN} / \mathrm{m})\end{array}$ & $\begin{array}{l}\text { COMPOSITE WITH SHEAR WALL } \\
(\mathrm{KN} / \mathrm{m})\end{array}$ \\
\hline Base & 0 & ( & 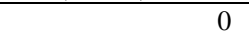 & ( \\
\hline 1 & 1292503 & 6903487.031 & 2114177.636 & 8671133.005 \\
\hline 2 & 774342.8 & 3580772.778 & 1084590.899 & 4557050.78 \\
\hline 3 & 714501.7 & 2603232.877 & 931641.314 & 3380857.809 \\
\hline 4 & 697616.7 & 2100287.83 & 885008.033 & 2744738.727 \\
\hline 5 & 690112.3 & 1790395.946 & 868738.96 & 2341520.377 \\
\hline 6 & 684098.4 & 1576977.717 & 860705.989 & 2056837.42 \\
\hline 7 & 679372.2 & 1422627.942 & 857024.369 & 1845012.295 \\
\hline 8 & 674405.3 & 1307964.745 & 853859.368 & 1683578.05 \\
\hline 9 & 670043.8 & 1223756.894 & 851149.968 & 1562652.152 \\
\hline 10 & 665350.3 & 1163540.138 & 848342.788 & 1475294.03 \\
\hline 11 & 660542.6 & 1122271.362 & 844653.719 & 1415875.442 \\
\hline 12 & 656247 & 1096152.405 & 841706.512 & 1378940.327 \\
\hline 13 & 651791.5 & 1079304.053 & 839213.043 & 1355954.249 \\
\hline 14 & 647886.4 & 1065735.302 & 837528.542 & 1337481.054 \\
\hline 15 & 645048.4 & 1049062.173 & 838233.66 & 1313068.196 \\
\hline 16 & 641406.4 & 1018441.574 & 839112.705 & 1268493.341 \\
\hline 17 & 635356.8 & 960059.353 & 836997.76 & 1186967.922 \\
\hline 18 & 622575.9 & 855676.38 & 826986.996 & 1046213.631 \\
\hline 19 & 580528.6 & 670223.997 & 776934.689 & 806723.924 \\
\hline 20 & 412496.8 & 361815.448 & 546004.379 & 430153.909 \\
\hline
\end{tabular}




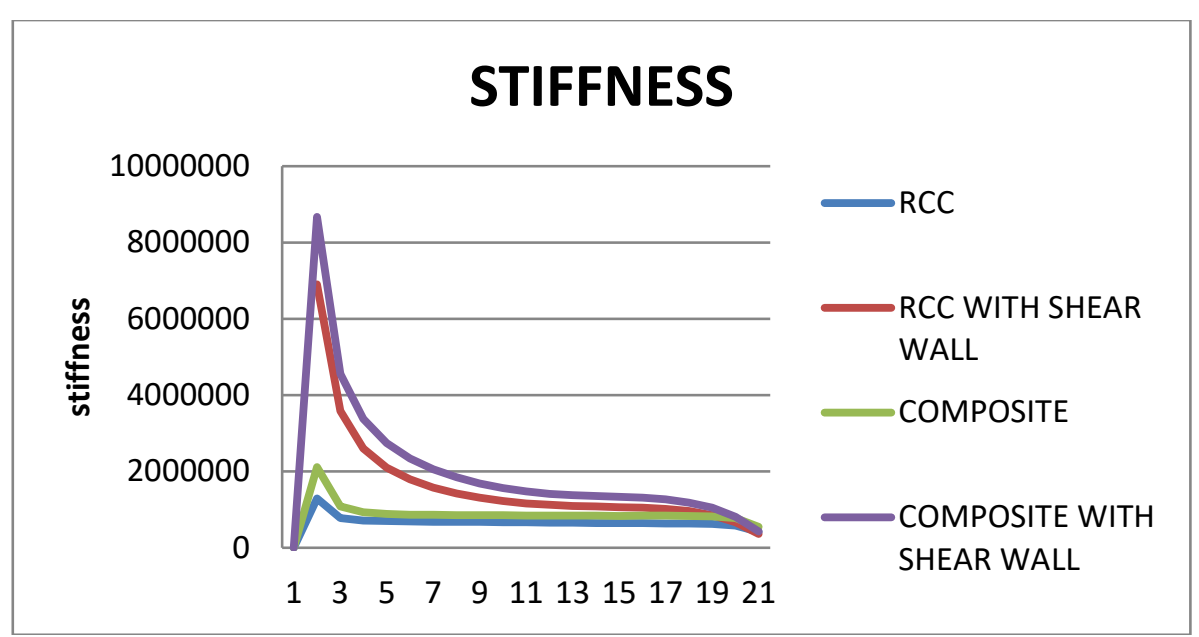

Fig 12: Comparison of stiffness by response spectrum method

\section{CONCLUSION}

- From all the above analysis, it is observed that for high rise building of 20 storey, building with composite column is more efficient. It is observed that displacement and drift is reduced substantially and stiffness of the building increases in presence of shear walls. Hence it is concluded that composite column building with shear wall counter seismic force more as compared to other models.

- In case of RCC framed structure the lateral displacement is very high. It is observed that in presence of shear wall the displacement at top reduces by approx $40 \%$ in case of static analysis and $47 \%$ in case of response spectrum analysis in both RCC and composite column buildings. Also the building with composite column reduces the displacement by approx $20 \%$ as compared to RCC building.

- Hence the composite column building in presence of shear wall counters the seismic effect more efficiently.

- Storey-drift is the relative displacement, it means the drift of one level relative to the level below. It is observed that the drift at top is reduced by $13 \%$ in presence of shear wall in case of static analysis and $23 \%$ in case of response spectrum analysis.

- Building with composite columns reduces the drift by approx $25 \%$ compared to RCC column buildings.

- The stiffness of the building is more in case of composite column compared to RCC column building. The shear wall in the building makes the building increases the stiffness of the building.

\section{REFERENCE}

[1] IS 1893 (part 1): (2002), "Criteria for Earthquake Resistant Design of Structures Part 1 General Provisions and Buildings", Bureau of Indian Standards.

[2] IS: 11384, code of practice for composite construction in structural steel and concrete, Bureau of Indian Standards, New Delhi, 1985

[3] CSI Computers and Structures INC. "Introductory Tutorial for Etabs: Linear and Nonlinear Static and Dynamic Analysis and Design of Three-Dimensional Structures" 2017

[4] B.C. Punmia, A.K. Jain, 2006, R.C.C Designs", Laxmi Publications New Delhi.

[5] IS-456 2000 plain and reinforced concrete code of practice.

[6] Panchal D.R., and Marathe P.M., "Comparative study of R.C.C, Steel and Composite $(\mathrm{G}+30)$ Building" Institute Of Technology, Nirma University, Ahmadabad, 2011.

[7] Prof. Charantimath, S.S., Prof. Cholekar, Swapnil B, and Birje, Manjunath M. (2014) "Comparative Study on Structural Parameter of R.C.C and Composite Building" IISTE, ISSN 2224-5790 (Paper) ISSN 2225-0514, 6(6) 98-109

[8] Kiran Tidke, Rahul Patil and Dr. G.R. Gandhe, "Seismic Analysis of Building with and Without Shear Wall”, International Journal of Innovative Research in Science, Engineering and Technology (JIRSET). Vol.3, pp.17852-17858, October 2016.

[9] N. Venkata Sairam Kumar, R. Surendra Babu and L. Usha Kranti, "Shear walls - A review", International Journal of Innovative Research in Science

[10] S.G. Satpute and D.B. Kulkarni, "Comparative study of reinforced concrete shear wall analysis in multi-storeyed building with openings by nonlinear methods", International Journal of Structural and Civil Engineering Research (IJSCER). Vol.2, pp. 183-193, August 2013. 